\title{
統合失調症における非情動的・情動的情報に対する選択的注意機能の 検討 ${ }^{1)}$
}

\author{
室 井 み や2) (近畿福祉大学社会福祉学部) \\ 笠 井 清 登 (東京大学大学院医学研究科) \\ 植 月 美 希 (東京大学大学院人文社会系研究科) \\ 管学 （東京大学大院医学研究科)
}

The function of selective attention to non-emotional and emotional information in patients with schizophrenia

Miya MUROI (Faculty of Social Welfare, Kinki Welfare University)

Kiyoto KASAI (Graduate School of Medicine, University of Tokyo)

Miki UETSUKI (Graduate School of Humanities and Sociology, University of Tokyo)

Motomu SUGA (Graduate School of Medicine, University of Tokyo)

The function of selective attention for emotional and non-emotional information in schizophrenic patients is examined with the Stroop task and an emotional Stroop task. In the Stroop task, no significant differences in response times were observed between the incongruent and neutral conditions with schizophrenic patients, although the difference in error rates for the incongruent and neutral conditions was larger for schizophrenic patients than for the control group. These results suggest that for schizophrenic patients the suppression function for irrelevant information is lower and that it is difficult to maintain task demands.

In the emotional Stroop task, response times and error rates did not differ across word conditions. This suggests that the cognitive functional difficulties of schizophrenic patients for emotional information is due to reduced processing for emotional information rather than an attentional bias for emotional information.

Key words : schizophrenia, emotional information, selective attention

ストループ課題および情動ストループ課題を用いて, 統合失調症における情動的情報, 非情動的情報に関 する選択的注意機能について検討を行った。 その結果，ストループ課題において，統合失調症者では不一致 条件と中性条件の反応時間の違いは有意ではなかったが，統制群に比べて，不一致条件と中性条件の䛊答率 の違いは大きかったことから，無関連情報の処理を抑制する機能が低下していること，課題要求の保持が難 しいことが示された.

また，情動ストループ課題では，単語の種類による反応時間の違い，誤答率の違いは全体として有意では なかったことから，情動的情報の認知機能障害は，情動的情報への注意バイアスによるものではなく，情動 的情報に関する処理機能自体が低下しているためである可能性が示された.

キーワード : 統合失調症, 情動的情報, 選択的注意

統合失調症では, $85 \%$ の患者で記憶・学習や注意に 関連するさまざまな認知機能に障害が見られる。また， 認知機能の中でも, 情動に関連する情報の認知機能障害 が多く見られ，特に，情動的情報の認知機能障害が発病 に伴う対人関係の悪化や妄想形成などにも深く関わって いると考えられている (Gooding \& Tallent, 2002;

1）審査者の先生方から貴重なご意見をいただきました. ここに記して，感謝いたします。

2) 現所属：群馬大学教育学部
Hooker \& Park, 2002; Kee, Green, Mints, \& Brekke, 2003; Brune, 2005). さらに, 認知機能障害は陰性症状 や陽性症状よりも，心理社会的機能の障害と関係してい ることが示されている (Hooker \& Park, 2002). こう いった認知機能障害については, そのメカニズムを検討 するための実験心理学的手法に加え, 症状の多様性を検 討するために神経心理学的検査が用いられてきたが (中 込，2005), その仕組みについての見解は一致していな い (Baudouin, Martin, Tiberghien, Verlut, \& Franck, 2002; Edwards, Jackson \& Pattison, 2002; Kee et al., 
2003; Suslow, Roestel, Droste, \& Arolt, 2003; van Rijn, Aleman, Swaab, \& Kahn, 2004; Brune, 2005). そのため, 今後の研究において認知機能障害のメカニズ ムについて明らかにすることは, 治療の方針や QOL を 高めるための方法を検討するうえであ重要であると考え られる.

一方で, 恐怖症やうつ病など不安障害や気分障害にお いても, その症状は統合失調症とは異なるものの, 同じ く情動に関する認知機能の障害がみられる. 気分障害に ついては, 認知心理学的研究によって, 恐怖の対象と なったり，ネガティブな意味を持つ情動的情報に注意を 向けてしまうという注意バイアスの存在がその症状と深 く関わっていることが示されている (Williams, Mathews, \& MacLeod, 1996). 統合失調症においては 一般的な注意機能障害は指摘されている屯のの, 情動的 情報の認知障害のメカニズムについて検討した研究は多 くなく,そのメカニズムについての議論は一致していな い(レビューとして Pinkham, Penn, Perkins, \& Lieberman, 2003). 本研究では, 認知心理学の分野で, 注意機能について検討するために多く用いられてきたス トループ課題, およびその類似課題である情動ストルー プ課題を用いて, 統合失調症における情動的情報, 非情 動的情報の認知障害のメカニズムについて検討すること を目的とする.

\section{ストループ課題}

ストループ課題とは, Stroop (1935) で最初に使用さ れた課題であり, 人の選択的注意の機能を反応時間や誤 答率などの客観的指標を用いて示すことができる課題で ある。また, 課題を応用して, さまざまな認知的側面が 測定できるというという理由により, 現在まで心理学の 領域で多く用いられてきた. 基本的なストループ課題は, 色を示す単語（例として“red”）に色をつけて呈示し, 単語ではなく色そのものを答える課題であるが, 単語が 示す色と単語を呈示する色が不一致なときに, 反応時間 が遅れたり, 誤答が増加したりする干渉と呼ばれる現象 がみられる. 干渉は, 単語を示す色に注意を向け, 単語 自体は課題とは関連しないにもかかわらず, 単語の意味 が処理されることによって, 課題遂行に影響があるため に起こると考えられる.このことは, 課題と無関連な情 報には注意を向けていないにもかかわらず，何らかの処 理が進行していることを示している．近年ではさらに， 医療場面においても, さまざまな疾患に関する認知機能 障害, 特に, 注意機能障害について調べるために使用さ れている (MacLeod \& MacDonald, 2000).

\section{統合失調症とストループ課題}

ストループ課題を応用した研究の 1 つとして, 統合 失調症に関する注意機能障害についての研究が挙げられ る (Delamillieure, Constans, Fernandez, Brazo, \&
Dollfus, 2004; Barch, Carter, \& Cohen, 2004; Henik \& Salo, 2004; Fuentes, Boucart, Vivas, Alvarez, \& Zimmerman, 2000; Barch, Carter, Hachten, Usher, \& Cohen, 1999; Barch, Carter, Perlstein, Baird, Cohen, \& Schooler, 1999; Boucart, Mobarek, Cuervo, \& Danion, 1999; Schooler, Neumann, Caplan, \& Roberts, 1997 など). これらの研究で使用したスト ループ課題は 2 つのタイプに分けることができる. 1 枚 の用紙に複数の単語を異なる色で呈示し, そのすべての 色を答えるまでの時間を測定する初期のカード版（複数 呈示型）ストループ課題と, 画面に 1 度に 1 単語ずつ を呈示し，1 試行ごとに反応時間を測定する個別呈示型 ストループ課題である. 個別呈示型課題では, 反応時間 を算出する際に䛊答を取り除くことができるため, より 正確に反応時間を算出できるなどの理由で, 最近では特 に多く用いられている. 健常者のデータでは, 複数呈示 型課題と比較すると, 個別呈示型課題で干渉量が減少す るあのの, 基本的に同様の結果が示されてきた.

しかしながら, 統合失調症の患者を対象とした研究で は, 健常者のデータとは異なる結果が示されている. 複 数呈示型ストループ課題を使用した初期の研究では, 統 制群の参加者に比べて, 統合失調症の参加者で, 反応時 間が全体的に長くなること, および干渉量が増えること が報告されている (Henik \& Salo, 2004). しかし, 個 別呈示型のストループ課題を用いた多くの研究では, 統 合失調症群では, 統制群の参加者と比較して全体的に反 応時間は長いむのの, 反応時間を指標とした場合, 干渉 量の増加はみられず, 誤答率を指標とした場合に干渉量 が増加することが示されている (Carter, Robertson, \& Nordahl., 1992; Cohen, Barch, Carter, \& ServanSchreiber, 1999; Schooler et al., 1997).

さらに, 個別呈示型ストループ課題においても, 同時 に呈示する刺激の有無 (Boucart et al., 1999) や試行間 間隔 (Salo, Henik, Nordahl, \& Robertson, 2002)に よって, 干渉量が影響を受けることが示されている. Boucart et al. (1999) では, ターゲットとなる関連情報 の周囲に無関連情報が同時に呈示された場合にのみ, 統 合失調症の参加者で干渉量が増大することが示された。 これらの結果は, 統合失調症者が, 関連する刺激のある 場所に注意を向け, 周りの刺激を抑制することが困難で あることを示しており (Boucart et al., 1999), 複数呈 示型ストループ課題では, 健常者に比べて統合失調症者 で干渉量が多いという結果とも一致する.

また, 試行間間隔が 2000 ミリ秒以上になると, 健常 者では, 干渉量が減少したり, 誤答が減少したりするこ とが示されているが, 逆に統合失調症患者では干渉量が 増えたり, 誤答が増えたりする (Salo et al., 2002). こ の結果は, 健常者では試行間間隔が長くなると, 準備の 
時間が長くなるため, より効果的に関連情報に注意を向 けることができるが，統合失調症患者は試行間間隔が長 くなると，単語の読みではなく，色を答えなければなら ないという課題の要求を保持することがより難しくなる と考えられている (Henik \& Salo, 2004).

\section{情動ストループ課題}

ストループ課題は注意のさまざまな側面を明らかにす るために用いられてきたが, あともとの単語を呈示する 色を答える課題だけでなく, 数字自体を無視し, 数字の 個数を答える課題 (Pavese \& Umilta, 1998; Muroi \& MacLeod, 2004), 線画の中に書かれた単語を無視し, 線画が示しているあのを答える課題（石王，1990）な ど，さまざまな応用課題が考案されており，その 1 つ に情動ストループ課題が挙げられる.

情動ストループ課題は, 通常の色単語を刺激として使 用するストループ課題とは異なり, 情動的な単語を呈示 し, その単語の色を答える課題であり, 反応時間のパ ターンから, 情動的情報に対する注意バイアスについて 検討することができる (MacLeod \& MacDonald, 2000). 具体的には, 色単語の变わりに, 例えば, 情動的な単語 （例として“死”や“くも”など）が示され，その単語 の色を答える. 健常者では, 情動的な単語であっても, 非情動的な単語と比べて反応時間や正答率に差はみられ ないが，うつ病などの気分障害，恐怖症などの不安障害 などの患者では，その症状に関連する単語の色を答える 場合の反応時間が長くなることが示されている。この結 果は気分障害や不安障害などにおいて, 情動に関わる情 報へ注意がひきつけられてしまう注意バイアスが症状と 深く関わっていることを示唆している，また，健常者で は情動的な情報であっても注意がひきつけられないよう にする抑制的な機能が存在するため, 注意バイアスが見 られないと考えられている (Williams et al., 1996).

本研究では, ストループ課題, 拉よび情動ストループ 課題を用いて, 統合失調症患者における注意の機能につ いて検討する。具体的方法として，ストループ課題，お よび情動ストループ課題を用いた 2 種類の実験を行い, 健常者のデー夕と比較することで, 統合失調症に打ける 選択的注意の機能, おょび情動的情報への注意バイアス の有無について検討を行う。実験 1 では, 通常のスト ループ課題を行い, 先行研究との比較を行う. 実験 2 では, 実験 1 と同じ参加者により, 情動語を用いた情 動ストループ課題を行い, 情動情報への注意バイアスに ついて検討する. そして, これらの結果を元に, 統合失 調症における情動的情報の認知障害の仕組みについて検 討する.

\section{実 験 1}

これまでの個別呈示型ストループ課題を用いた研究で
は, 統合失調症者では健常者に比べて, 干渉量は増えな いものの，䛊答率が高くなることが示されている。また， 刺激呈示間間隔や周りに無関連情報を呈示するから゙うか という条件により干渉量が変化することから, 統合失調 症者では, 注意の焦点化や課題要求の保持が困難である と考えられている。本実験では, 個別呈示型ストループ 課題を行い, 統合失調症者, 抒よび健常者に打ける反応 時間，および誤答率の比較を行い，選択的注意機能につ いて検討する.

\section{方法}

\section{実験参加者}

統合失調症患者 28 名㧍よび健常者 41 名が実験に参 加した。 統合失調症群の平均年齢は 35.6 (16 57) 歳, 統制群の平均年齢は $26.8(20 \sim 42)$ 歳であった。

統合失調症患者は，主治医を通じて個別に，あるいは デイケアで募集した入院患者 10 名, 外来患者 18 名で あった。健常者は, 知人を通じて個別に, あるいはウェ ブサイト広告を通して募集した。統合失調症の診断は DSM-IV に基づいて行い, DSM-IV による亜型分類で は, 妄想型 9 名, 解体型 6 名, 緊張型 0 名, 鑑別不能 型 13 名, 残遺型 0 名であった。初発統合失調症は 3 名 含まれていた。本研究は, 東京大学医学部倫理委員会の 承認を得ている (承認番号 629). すべての参加者に 対し, 研究の主旨を十分説明した後, 書面にて自由意志 による同意を得た。

\section{実験デザイン}

被験者間要因として参加者グループ（統合失調者群抢 よび統制群), 被験者内要因として単語の示す色と単語 を呈示する色の一致性（不一致または中性）.

\section{実験材料}

不一致条件では, 色を示す 4 種類の漢字（赤，緑, 青, 黄) を用いた。 それぞれの漢字は試行ごとに, 赤, 緑, 青, 黄のいずれか 1 色で呈示したが, 漢字の示す 色と呈示色が同じ一致条件（赤い色で “赤”など）は除 いた。 中性条件では色をイメージしにくい４種類の漢 字（公, 生, 左，大）を使用し, 不一致条件之同様に, 試行ごとに異なる色で呈示したが，不一致条件と刺激の 種類数を同じにするために，それぞれの漢字で異なる 1 種類の色を除いた。 また，一致条件を除いたのは，これ までの研究において, 一致条件の解釈が難しいこと (Pavese \& Umilta, 1998), 一致条件でみられる促進の 効果はみせかけであるとの指摘がなされていることから である (MacLeod \& MacDonald, 2000). 分析の際には, 漢字の種類にかかわらず一致性およびグループで平均を 求めた. 文字の大きさは $3.5 \times 3.5 \mathrm{~cm}$ で画面中央に呈示 した. 画面の色は, 白. 実験参加者とモ二ターの距離は, $65 \mathrm{~cm}$ であった. 


\section{手続き}

毎試行, 注視点 $(+)$ を 1 秒間呈示し, 漢字を呈示し た. 漢字はマイクを通して, 声が入力されるまで呈示さ れた. マイクに声が入力されてから 1500 ミリ秒経過す ると, 次の試行が始まった. 1 ブロックは不一致条件 12 試行, 中性条件 12 試行の合計 24 試行からなり, 合 計 3 ブロックの計 72 試行を行った。 実験参加者は本試 行に先立ち，24試行の練習試行を行った．画面中央の 注視点に注目し，漢字が現れると，その漢字の特性は無 視して，漢字を呈示する色をできるだけ早く，できるだ け正確に声に出して答えるよう求めた。 反応内容は, 実 験者が実験中に記録し，実験後の分析に使用した。

\section{装置}

刺激呈示および反応測定は，Dell Dimension 4300 を用い，実験用ソフト Cedrus Super Lab Pro 2.04 を 使用し， 17 インチの IIYAMA A702H モニターに呈示 された. 参加者の反応時間は, PST serial response box \#200a, および実験参加者の口の前に設置した付属 のマイクを使用し，計測を行った。

\section{結果}

実験参加に当たっての問題はみられなかったため, 全 ての参加者を分析の対象とし，個人ごとに不一致条件と 中性条件において誤答，およびはずれ值（2 sd を超え た反応）を除き，反応時間，および誤答率を求めた。 2 sd を超えた試行は統合失調症群の不一致条件之中性条 件で $4.76 \%$ と 4.56\%，統制群で 4.40\%と 3.79\%であっ た。それらを元に統合失調症群, 統制群ごとに求めた平 均反応時間（Figure 1 上）, および平均誤答率（Figure 1 下) を示す.

反応時間について，グループおよび一致性に関する 2 要因分散分析の結果, グループおよび一致性の主効果, グループと一致性の交互作用がすべて有意であった（そ れぞれ $F(1,67)=39.41, p<.001, \quad F(1,67)=4.39, p<$ $.05, F(1,67)=4.53, p<.05)$. 単純主効果の検定を行っ た結果, 不一致条件, 中性条件ともに統合失調症群の反 応時間が統制群よりあ長くなった $(p<.001)$. また，統 制群では, 不一致条件での反応時間は中性条件よりも有 意に長かったが $(p<.001)$, 統合失調症群では不一致条 件と中性条件の差は有意ではなかった $(p>.10)$.

さらに, 病態別に結果を検討するため, 統合失調症群 について, 年代 $(10 \sim 20$ 代 7 名, 30 代 14 名, 40 50 代 7 名), 初発 (3 名) 加再発 (25 名), 入院（18 名) 加来（10 名）か, 経過年数（10 年未満 14 名, 10 年以上 14 名) ごとに，それぞれ一致性を被験者内 要因として 2 要因分散分析を行った. その結果, 年代 之一致性の分析において交互作用が有意であり $(F(2$, $25)=7.19, p<.005)$ ， 下位検定の結果， 40〜50 代のグ
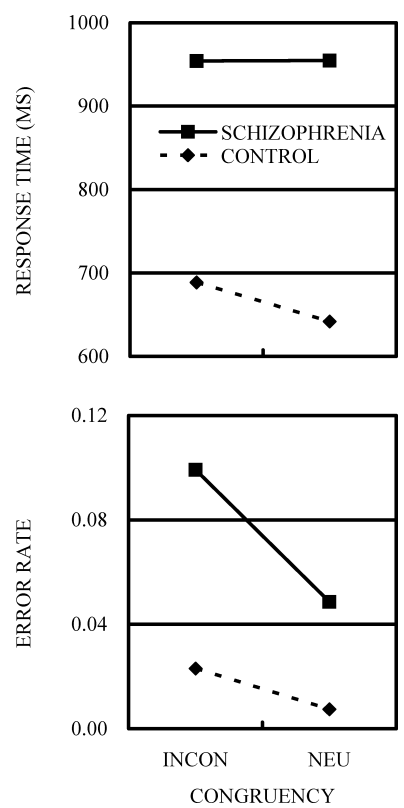

Figure 1. Experiment 1: Mean response times and mean error rates in the Stroop task as a function of the congruency and the group. INCON (incongruent condition), NEU (neutral condition).

ループでは不一致条件の反応時間は中性条件の反応時間 より屯短かった $(p<.05) .10$ 代〜20 代および 30 代の グループでは一致性による違いは有意ではなかった $(p>.10)$. 経過年数に関する分散分析では交互作用が有 意傾向であり $(F(2,25)=3.03, p<.10)$, 下位検定の結果, 中性条件では, 10 年以上のグループの反応時間は 10 年以下のグループよりあ, 長い傾向であった $(p<.10)$. 初発再発, 入院・外来別, 経過年数に関する分散分析 では交互作用は有意ではなかった（それぞれ $F(2,25)=$ $0.00, p>.10, F(2,25)=1.99, p>.10)$.

䛊答率についてもグループ（統合失調症群と統制群） と一致性に関する 2 要因分散分析を行ったところ,グ ループおよび一致性の主効果, グループと一致性の交互 作用が全て有意であった（それぞれ $F(1,67)=20.01$, $p<.001, \quad F(1,67)=38.07, \quad p<.001, \quad F(1,67)=10.66$, $p<.005)$. 単純主効果の検定の結果, よ゙ちらのグループ でも不一致条件の誤答率が中性条件よりも高く, どちら の条件でも統合失調症群の䛊答率は統制群参加者のもの よりあ高くなった $(p<.001)$. グループによる干渉量の 違いを検討するために, 不一致条件と中性条件の誤答率 の差について一要因の分散分析を行ったところ, 統合失 調症群では, 統制群に比べて, 不一致条件と中性条件の 
誤答率の差は有意に大きかった $(F(1,67)=10.66, p<$ .005).

さらに，反応時間の場合と同様に病態別に結果を検討 するため, 統合失調症群について, 年代, 初発か再発,

入院・外来, 経過年数ごとに, それぞれ一致性を被験者 内要因として 2 要因分散分析を行った。 その結果，交 互作用は全て有意ではなかった $(F(2,25)=2.22, p>.10$, $F(1,26)=0.00, p>.10, F(1,26)=1.96, p>.10, F(2,25)$ $=0.02, p>.10)$.

\section{考察}

本実験では, 統合失調症群では統制群に比べて, 全体 的に反応時間が長くなった。しかし, 統制群とは異なり, 統合失調症群では一致性による反応時間の違いは有意で はなかった，誤答率については，統合失調症群で統制群 に比べて全体として高くなり，また，不一致条件と一致 条件の誤答率の差についても, 統合失調症群では統制群 に比べて大きくなった。つまり, 統合失調症群では, 一 致性にかかわらず反応が遅く, 誤答が多く, 干渉量の増 加は誤答率のみに現れていた。このことは, 統合失調症 群では, 中性条件であっても, 呈示された刺激に対して 色という 1 つの特街に注意を向けることがより難しく, 不一致条件之同様に反応時間が遅れ，さらに不一致条件 では無関連情報の処理を抑制することがより困難であっ たため, 誤答が増えたと考えられる。つまり, 統制群に 比べ，無関連情報を抑制する機能が低下していることが 示された.

反応時間に関して, 統合失調症群で干渉が有意でな かったことについては，試行間間隔の違い，実験で使用 した言語の違いなども影響した可能性が考えられるが, 不一致条件で䛊答率が高いことからも示されるように, 関連情報, 無関連情報にかかわらず，できるだけ早く回 答したためと推測される。つまり，単語の色に注意を向 け，単語の読みには注意を向けないという課題要求に答 えられなかったためと考えられる。病態別の分析の結果, 40〜50 代のグループで中性条件の反応時間が長くなっ たこと, 発症後 10 年以上のグループでは 10 年以下の グループに比べて中性条件の反応時間が長くなる傾向が あったことに関しては，単語の読みではなく色を答える という課題要求に応じる際に混乱が生じていた可能性も 考えられるが，さらに詳細な病態別の検討が必要である 之考えれる.

以上から，統合失調症群では，不一致条件だけでなく， 中性条件においても単語の読みを無視し, 単語を呈示す る色に注意を向けるという抑制機能が低下している可能 性が示された。

\section{実 験 2}

統合失調症者では注意機能障害がみられることが示さ れている(Henik \& Salo, 2004). 実験 1 の色ストルー プ課題に扔いて, 健常者と比べて, 統合失調症者では反 応時間が全体的に長いが干渉はみられず，誤答率につい ては, 健常者に比べて高く, 干渉量も多いといった特徵 がみられた。これは健常者に比べ, 選択的注意の機能が 低下しているため, 無関連情報処理の抑制が難しいこと を示している. 加えて, 䛊答率で示されるように, 不一 致条件においては注意による無関連情報の抑制がさらに 難しいことを示している.

一方, 統合失調症者では, 顔の表情や声などから情動 を知覚すること，特にネガティブな感情を知覚すること が困難であるという情動的情報の認知障害がみられるこ とが示されている (Gooding \& Tallent, 2002; Hooker \& Park, 2002; Kee et al., 2003; Brune, 2005). そこで 実験 2 では, 統合失調症における情動的情報の処理の 特徵について, 情動ストループ課題を用いて検討する. 情動ストループ課題において, 情動と関連する特定の単 語を呈示する色を答える場合に反応時間が遅れたり, 誤 答率が高くなったりするなど，干渉がみられれば情動的 情報に対する注意バイアスがあると考えられる。そこで， 本実験では, 統合失調症之関連する不快単語（統合失調 症ネガティブ語), 一般的な不快単語 (一般ネガティブ 語), 情動的に快単語（ポジティブ語）を材料として, 単語を呈示する色を答える場合に, 情動的に中性な単語 （中性語）と比べて反応時間や誤答率に違いがあるかど うかを比較し, 注意バイアスの有無について検討する.

\section{方法}

\section{実験参加者}

統合失調症患者 25 名, および健常者 41 名が実験に 参加した. すべての参加者は実験 1 にも参加している. 統合失調症患者の内訳は, 入院患者 8 名, 外来患者 17 名, 妄想型 7 名, 解体型 6 名, 緊張型 0 名, 鑑別不能 型 12 名, 残遺型 0 名であった.

\section{実験デザイン}

参加者グループ（統合失調症群・統制群）之単語種類 (統合失調症ネガティブ語, 一般ネガティブ語, ポジ ティブ語, 中性語) の 2 要因計画.

\section{実験材料}

実験材料の選定に当たっては, 以下の手続きを行った. Epstein, Stern, \& Silbersweig (1999) を参考に, 統合 失調症者にとってのネガティブ単語（統合失調症ネガ ティブ語） 40 語, 一般的なネガティブ語（一般ネガ ティブ語) 83 語, 一般的なポジティブ語 (一般ポジ ティブ語） 20 語, 情動的に中性な単語（中性語） 111 
Table 1 Words used in experiment 2.

\begin{tabular}{|c|c|}
\hline $\begin{array}{c}\text { 統合失調症関連 } \\
\text { ネガティブ語 }\end{array}$ & 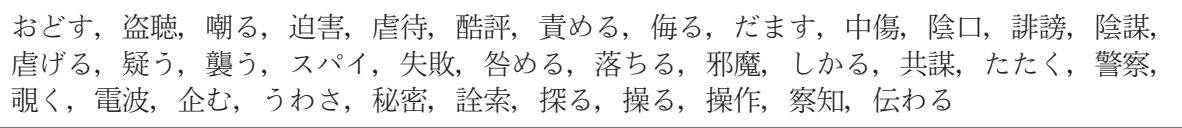 \\
\hline $\begin{array}{l}\text { 一般ネガティブ } \\
\text { 語 }\end{array}$ & 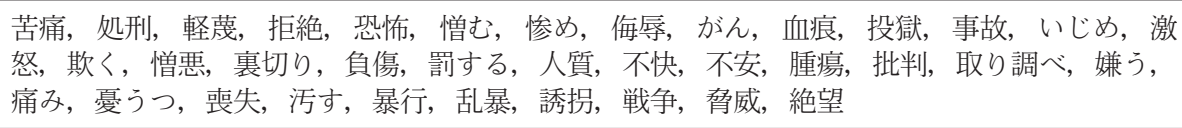 \\
\hline 中 性 語 & $\begin{array}{l}\text { 駐車, 老人, 税関, 指導, 注意, 割合, 歩行, 厚紙, 廊下, 位置, 見本, 親指, 定規, 比喻, } \\
\text { 天井, 倉庫, 分割, 帽子, 鉛筆, 地面, 転送, 傾向, 天候, 乱数, 審査, 手軽, 回る, 換気 } \\
\text { 扇, 掲載, 特異的, 店舗, 四角, 時計, 特定, 付添い, 水圧 }\end{array}$ \\
\hline ポジティブ語 & $\begin{array}{l}\text { 住む, 情熱, 考慮, 住居, 淡い, 磨く, 前進, 理想, 地元, 毛布, 発明, 珈琲, 万能, 整え } \\
\text { る, 賢い, 芝生, 居住, 家庭, 信頼, 親切, 愛情, 明朗, 豊か, 木製, 旅行, 良好, 前向き, } \\
\text { 花びら, 散歩, 快感, 愉快, 活気, 楽しい，穏やか, 喜び, 幸福 }\end{array}$ \\
\hline
\end{tabular}

語を選び，親密度掞よび快・不快度に関して質問紙によ る調查を行った。親密度に関する調査では，「全く見た り聞いたりしない」の 1 点から「非常にしばしばみた り聞いたりする」の 5 点までの 5 段階, 快・不快度に 関する調査では「非常に不快」の 1 点から「非常に心 地よい」の 5 点まで 5 段階で評定を行った. 評定者の 負担を減らすため, すべての単語を 2 つのリストに分 け, 親密度は, 14 名之 10 名, 快・不快度は, 20 名之 17 名の健常者の大学生㧍よび大学院生が評定を行った. それらの結果に基づき, 実験で使用する単語を決定し た (Table 1). 統合失調症関連ネガティブ語および一般 ネガティブ語では, 快・不快度の評定で点数の低い（不 快度の高い) 単語を 36 語ずつ, 中性語では評定値の中 央付近の 36 語, ポジティブ語では快・不快度の評定で 点数の高い（快）単語を 36 語選定した. 快・不快度抒 よび親密度の平均值はそれぞれ, 統合失調症ネガティブ 語で 2.11 点と 3.43 点, 一般ネガティブ語で 1.71 点と 3.57 点, 中性語で 3.01 点と 3.60 点, ポジティブ語で 3.99 点と 3.80 点であった.

それぞれの種類の単語をランダムに 12 語ずつに分け, 全ての種類の単語からなる計 48 語のリストを 3 リスト 作成した. 各リストのそれぞれの種類の単語は, 3 語ず つ, 赤, 緑, 青, または黄で呈示した. 1 文字の大きさ は $2.3 \times 2.3 \mathrm{~cm}$ で, 単語は 2 文字または 3 文字であっ た。画面の色, 抄よび実験参加者とモニターの距離は実 験 1 と同様であった.

\section{手続き}

毎試行, 注視点 $(+)$ を 1 秒間呈示し, その後単語を 呈示した。単語は, 声の反応がマイクを通して入力され るまで呈示された。声がマイクに入力されてから 1,500 ミリ秒経過すると, 次の試行が開始された。画面中央の 注視点に注目し, 単語が現れると, その単語の特性は無
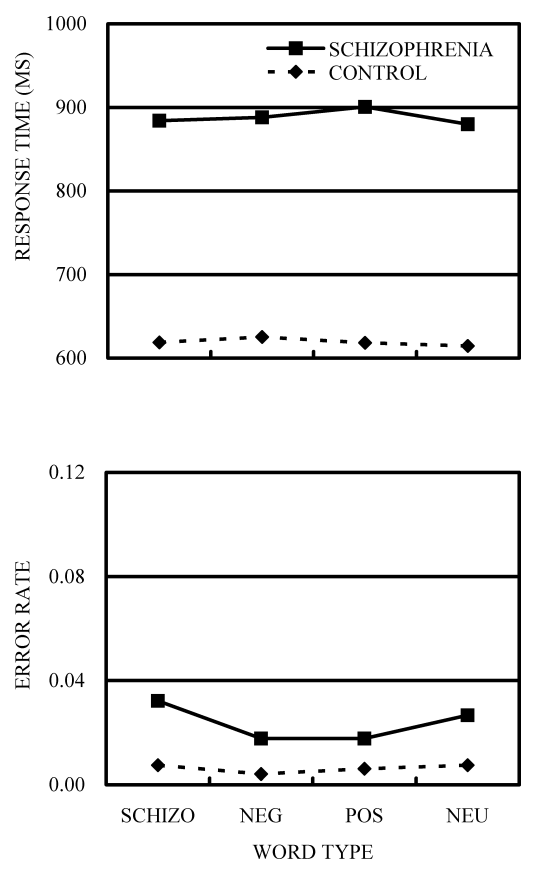

Figure 2. Experiment 2: Mean response times and mean error rates in the Emotional Stroop task as a function of the word type and the group. SCHIZO (schizophrenia related negative words), NEG (general negative words), POS (general positive words), NEU (neutral words).

視して，単語を呈示する色をできるだけ早く，できるだ け正確に声に出して答えるように求めた. 反応の記録拧 よび装置は実験 1 と同様であった。 


\section{結果}

実験参加に関して問題は見られなかったため，すべて の参加者を分析の対象とし，個人ごとにそれぞれの種類 の単語において䛊答，およびはずれ值（2 sd を超えた 反応）を除き，反応時間および䛊答率を求めた。はすれ 值として分析から取り除いた試行は, 統合失調症群で統 合失調症関連ネガティブ語 $4.33 \%$, 一般ネガティブ語 3.78\%， ポジティブ語 4.56\%， 中性語 4.44\%，統制群 で統合失調症関連ネガティブ語 $3.18 \%$, 一般ネガティ ブ語 3.05\%，ポジティブ語 4.07\%，中性語 3.32\%で あった。 それらの值を元に統合失調群, 統制群ごとに求 めた平均反応時間を（Figure 2 上），および平均誤答率 を(Figure 2 下) に示す.

反応時間についてグループおよび単語種類に関する 2 要因分散分析を行ったところ，グループの主効果が有意 で $(F(1,64)=44.60, p<.001)$, 統合失調症群では統制群 に比べて反応時間が長いことが示された。単語種類の主 効果扰よび交互作用は有意ではなく $(F(3,192)=1.91$, $p>.10, F(3,192)=1.31, p>.10), \quad$ どちらのグループに おいても単語の種類による違いは有意ではなかった.

さらに病態別に結果を検討するため, 統合失調症群に ついて，年代（10２0 代 6 名，30 代 13 名，40～50 代 6 名), 亜型分類 (妄想型 7 名, 非妄想型 18 名), 初 発（2名）再発（23 名)，入院（16名）加来（9 名) か, 経過年数 (10 年未満 12 名, 10 年以上 13 名) ごとに，それぞれ一致性を被験者内要因とした 2 要因 分散分析を行った. その結果, 交互作用は全て有意では なかった（それぞれ $F(6,66)=0.83, p>.10, F(3,69)=$ $1.06, p>.10, F(3,69)=0.63, p>.10, \quad F(3,69)=0.87$, $p>.10, F(1,26)=0.87, p>.10)$.

誤答率について，グループおよび単語種類に関する 2 要因分散分析を行ったところ，グループの主効果が有意 で $(F(1,64)=19.16, p<.001), \quad$ 統制群に比べて， 統合 失調症群では誤答率が高いことが示された。単語種類の 主効果については傾向差が見られたが，単語の種類によ る違いは有意ではなく, また, 交互作用は有意ではな かった $(F(3,192)=2.44, p<.10, F(3,192)=1.18, p>$ $.10)$.

さらに誤答率についても, 病態別に結果を検討するた め, 統合失調症群について, 年代, 亜型分類（妄想型か 非妄想型), 初発か再発, 入院か外来か, 経過年数ごと に，それぞれ一致性を被験者内要因として 2 要因分散 分析を行った。 その結果，年齢之一致性の交互作用が有 意傾向であり $(F(6,66)=2.04, p<.10)$, 下位検定の結果, 統合失調症関連ネガティブ語では，10２0 代のグルー プは 30 代および 40〜 50 代のグループに比べて誤答率 が高かった $(p<.05)$. また, 初発か再発かと一致性の交
互作用が有意であり $(F(3,69)=7.28, p<.001)$, 下位検 定の結果, 初発患者では統合失調症関連ネガティブ語の 誤答率が他の単語よりも高く, また, 再発患者と比べて 初発患者では, 統合失調症関連ネガティブ語の誤答率が 高かった $(p<.05)$. 亜型分類, 入院か外来か, 経過年数 に関する分析では交互作用は有意ではなかった（それぞ れ $F(3,69)=0.83, p>.10, F(3,69)=0.35, p>.10, F(3$, $69)=0.35, p>.10)$.

\section{考察}

情動ストループ課題において, 統合失調症群では単語 の種類にかかわらず反応時間が長く, 誤答率が高かった。 このことは，全般的な情報処理の機能の低下を示してい ると考えられるが, 実験 1 の結果とあわせて考えると, 選択的注意機能の低下む関与している可能性が考えられ る.

また，単語の種類による違いについては，反応時間, 䛊答率のどちらを指標とした場合でも，統制群と同様に， 統合失調症群でも有意ではなく, 情動的情報に関する注 意バイアスの存在は示されなかった。

一方, 病態別の分析に括いて, 統合失調症関連ネガ ティブ語の誤答率が 10〜20 代のグループおよび初発患 者で他のグループより高かったこと，初発患者では統合 失調症関連ネガティブ語の䛊答率が他の単語に比べて高 かったことは, 若年の患者や初発の患者においてのみ, 統合失調症関連語への注意バイアスが存在する可能性を 示唆している. しかし，年代別の分散分析での交互作用 は有意傾向でしかなかったこと，分析の対象となった初 発患者はたったの 2 名であったことから，この結果に ついては，今後，さらに検討する必要があるだろう。

\section{総 合考察}

本研究では, ストループ課題, および情動ストループ 課題の両方で，一致性または単語の種類にかかわらず統 合失調症群では反応時間が長くなり, 誤答率が高くなっ た.このことは統合失調症における全般的な情報処理の 遅れを示している. しかし, 実験 1 のストループ課題 において, 統合失調症群で, 統制群より不一致条件と中 性条件の誤答率の差が大きかったことは, 無関連情報の 処理を抑制すること, 課題要求を保持することが困難で あった可能性を示しており，統合失調症者に無関連情報 の処理を抑制する機能の障害があることを示した McGhie \& Chapman (1961)のフィルター理論の考え 方と一致する。

実験 2 の反応時間と誤答率について, 統合失調症患 者と健常者を比較した際には, 単語の種類による違いは みられず, 情動的情報への注意バイアスは示されなかっ た.この結果は, 統合失調症における情動的情報に関す 
る認知障害には, 情動的情報に対する注意バイアスが関 与していない可能性を示している. 今回の実験では単語 を材料として使用しているため, 表情や声などの情動的 情報の処理に関しても同様の結果がみられるかどうかは 不明であるが，情動的情報に対する注意バイアス以外の 原因が，情動的情報の認知障害を引き起こしている可能 性は高いと考えられる. その 1 つとして, 統合失調症 患者では, 健常者と比べて情動的処理に関与する脳部位 の賦活の程度が低いことを示した脳画像研究 (Takahashi, Koeda, Oda, Matsuda, Matsushima, Matsuura, Asai, \& Okubo, 2004) にも示されているよ うに, 情動的情報の処理機能自体が低下している可能性 が考えられる.

これらの結果は, 統合失調症患者に見られる認知機能 障害から起こる問題を軽減するための方法の 1 つとし て, 情報呈示の方法を工夫することが有効である可能性 を示している，例えば，必要な情報をできるだけ単独で 呈示する, 課題要求の保持が難しいことを考慮したわか りやすい課題呈示を行うことで, 選択的注意機能の障害 による問題を軽減できると考えられる。 また, 情動的情 報の認知機能障害については, 処理機能の低下を補うた めに, 必要な情動的情報についてはできるだけわかりや すく呈示するといった方法が有効であるかあしれない.

一方で, 若年患者, 初発患者に沶いて統合失調症関連 ネガティブ語の䛊答率が高くなる傾向があったことから， 若年, 初発患者については注意バイアスが存在するが, それ以外の患者では, それらの注意バイアスが克服され ている可能性も示唆される. しかしこの結果については, さらに病態別の詳細な検討が必要であるだろう。

本研究では, ストループ課題, および情動ストループ 課題を用いて, 統合失調症における情動的情報, 非情動 的情報に関する注意機能障害について検討した。 その結 果, 統合失調症患者では無関連情報の処理を抑制する機 能が低下していること, 課題要求の保持が難しいことが 示された。 また, 情動的情報の認知機能障害は, 情動的 情報への注意バイアスではなく, 情動的情報の処理機能 自体が低下しているためである可能性が示された.

\section{引用文献}

Barch, D. M., Carter, C. S., Hachten, P. C., Usher, M., \& Cohen, J. D. (1999). The "benefits" of distractibility: mechanisms underlying increased Stroop effects in schizophrenia. Schizophrenia Bulletin, 25, 749-762.

Barch, D. M., Carter, C. S., Perlstein, W., Baird, J., Cohen, J. D., \& Schooler, N. (1999). Increased stroop facilitation effects in schizophrenia are not due to increased automat- ic spreading activation. Schizophrenia Research, 39, 51-64.

Barch D. M., Carter, C. S., \& Cohen, J. D. (2004). Factors influencing Stroop performance in schizophrenia. Neuropsychology, 18, 477-484.

Baudouin, J, Y,, Martin, F., Tiberghien, G., Verlut, I., \& Franck N. (2002). Selective attention to facial emotion and identity in schizophrenia. Neuropsychologia, 40, 503511.

Boucart, M., Mobarek, N., Cuervo, C., \& Danion, J. M. (1999). What is the nature of increased Stroop interference in schizophrenia? Acta Psychologica, 101, 3-25.

Brune, M. (2005). Emotion recognition, 'theory of mind,' and social behavior in schizophrenia. Psychiatry Research, 133, 135-147.

Carter, C. S., Robertson, L. C., \& Nordahl, T. E. (1992). Abnormal processing of irrelevant information in chronic schizophrenia: selective enhancement of Stroop facilitation. Psychiatry Research, 41,137-146.

Cohen J, D., Barch, D. M., Carter, C., \& ServanSchreiber, D. (1999). Context-processing deficits in schizophrenia: converging evidence from three theoretically motivated cognitive tasks. Journal of Abnormal Psychology, 108, 120-133.

Delamillieure, P., Constans, J. M., Fernandez, J., Brazo, P., \& Dollfus, S. (2004). Relationship between performance on the Stroop test and $\mathrm{N}$-acetylaspartate in the medial prefrontal cortex in deficit and nondeficit schizophrenia: preliminary results. Psychiatry Research, 132, 87-89.

Edwards, J., Jackson, H. J., \& Pattison, P. E. (2002). Emotion recognition via facial expression and affective prosody in schizophrenia: a methodological review. Clinical Psychology Review, 22, 789-832.

Epstein, J., Stern, E., \& Silbersweig, D. (1999). Mesolimbic activity associated with psychosis in schizophrenia: symptom-specific PET studies. Annals New York Academy of Sciences, 877, 562-574.

Fuentes, L. J., Boucart, M., Vivas, A. B., 
Alvarez, R., \& Zimmerman, M. A. (2000). Inhibitory tagging in inhibition of return is affected in schizophrenia: evidence from the stroop task. Neuropsychology, 14, 134140 .

Gooding, D. C. \& Tallent, K. A. (2002). Schizophrenia patients' perceptual biases in response to positively and negatively valenced emotion chimeras. Psychological Medicine, 32, 1101-1107.

Henik, A. \& Salo, R. (2004). Schizophrenia and the stroop effect. Behavioral and Cognitive Neuroscience Reviews, 3, 42-59.

Hooker, C \& Park, S. (2002). Emotion processing and its relationship to social functioning in schizophrenia patients. Psychiatry Research, 112, 41-50.

石王敦子 (1990). 線画一単語課題に扮ける聴覚 一視覚間ストループ干渉 心理学研究, 61 , 329-335.

(Ishio, A. (1990). Auditory-visual Stroop interference in picture-word processing. The Japanese Journal of Psychology, 61, 329-335)

Kee, K. S., Green, M. F., Mintz, J., \& Brekke, J. S. (2003). Is emotion processing a predictor of functional outcome in schizophrenia? Schizophrenia bulletin, 29, 487-497.

MacLeod, C. M. (1991). Half a century of research on the Stroop effect: An integrative review. Psychological Bulletin, 109, 163203.

MacLeod, C. M. \& MacDonald, P. A. (2000). Inter-dimensional interference in the Stroop effect: Uncovering the cognitive and neural anatomy of attention. Trends in Cognitive Sciences, 4, 383-391.

McGhie, A. \& Chapman, J. (1961). Disorders of attention and perception in early schizophrenia. British Journal of Medical Psychology, 34, 103-116.

Muroi, M. \& MacLeod, C. M. (2004). Effect of separation on counting interference tasks. Japanese Psychological Research, 46, 56-64.

中込和幸 (2005). 統合失調症の認知障害とは何か 精神科治療学 20, 27-34

(Nakagome, K.)
Pavese, A. \& Umilta, C. (1998). Symbolic distance between numerosity and identity modulates Stroop interference. Journal of Experimental Psychology: Human Perception and Performance, 24, 1535-1545.

Pinkham, A. E., Penn, D. L., Perkins, D. O., \& Lieberman, J. (2003). Implications for the neural basis of social cognition for the study of schizophrenia. The American Journal of Psychiatry, 160, 815-824.

Salo, R., Henik, A., Nordahl, T.E., \& Robertson, L. C. (2002). Immediate versus sustained processing in schizophrenia. Journal of the International Neuropsychological Society, 8, 794-803.

Schooler, C., Neumann, E., Caplan, L. J., \& Roberts, B. R. (1997). A time course analysis of Stroop interference and facilitation: comparing normal individuals and individuals with schizophrenia. Journal of Experimental Psychology: General, 126, 19-36.

Stroop, J. R. (1935). Studies of interference in serial verbal reactions. Journal of Experimental Psychology, 18, 643-662.

Suslow, T., Roestel, C., Droste, T., \& Arolt, V. (2003). Automatic processing of verbal emotion stimuli in schizophrenia. Psychiatry Research, 120, 131-144.

Takahashi, H., Koeda, M., Oda, K., Matsuda, T., Matsushima, E., Matsuura, M., Asai, K., \& Okubo, Y. (2004). An fMRI study of differential neural response to affective pictures in schizophrenia. Neuroimage, 22, 12471254.

van Rijn, S., Aleman, A., Swaab, H., \& Kahn, R. S. (2004). Neurobiology of emotion and high risk for schizophrenia: role of the amygdala and the X-chromosome. Neuroscience and Biobehavioral Reviews, 29, 385397.

Williams, J. M. G., Mathews, A., \& MacLeod, C. (1996). The emotional Stroop task and psychopathology. Psychological Bulletin, 120, 3-24.

(2006 年 4 月 11 日受稿, 2006 年 9 月 13 日受理) 